\title{
Apple farming systems - Current initiatives and some prospective views on how to improve sustainability
}

\author{
P.É. Lauri ${ }^{1}$, B. Pitchers ${ }^{1}$, L. Dufour ${ }^{1}$, S. Simon ${ }^{2}$
}

${ }^{1}$ UMR SYSTEM, Institut National de la recherche Agronomique, Montpellier, France; ${ }^{2}$ UE695 Gotheron, Institut National de la recherche Agronomique, Saint-Marcel-lès-Valence, France

\begin{abstract}
Apple cultivation has evolved tremendously in past decades. Both apple productivity, and aesthetic and quality of the fruit, have been strongly improved resulting from genetic improvement, optimization of tree training and pruning, and orchard design and management. However, these improvements were also done at the expense of an increasing dependence on external inputs such as water, fertilizers and synthetic pesticides. This dependence is now questioned because of the generated environmental pollutions and health issues. In the last decades, an increasing amount of initiatives have been developed that open the way towards more sustainable apple production systems. Concepts as well as on-station and onfarm works are developed in various contexts such as 'Integrated Fruit Production', 'Organic Farming' and 'Agroecology' with the objectives to increase biological regulations of pests and diseases and/or to improve soil fertility. All together results point out the importance of diversifying resources and habitats for beneficial arthropods in the orchard and its vicinity to foster ecosystem services related to pest suppression and to adopt cultural practices enhancing soil fertility. They also indicate some practical guidelines consisting in a better management of grass alleys and lining hedgerows within and around the orchard, respectively. From a more prospective view and taking inspiration from tropical fruit-tree based agroforestry, these works suggest that combining apple trees with other herbaceous and woody plants with various uses (soft fruit, aromatic plants, etc.) opens to more resilient agroecosystems, possibly mitigating climate change. They also enlarge our vision of the current apple orchard towards a multiproduction system including apple among other productions. From the 'plant science' point of view this emerging paradigm challenges current knowledge of the plasticity of the apple tree physiology and architecture, and agronomic performance, in response to interactions with neighboring plants. It also stimulates necessary collaborations with other research fields such as socio-economics, for example on how the grower may handle those complex agroecosystems, optimize labor and valorize production.
\end{abstract}

Keywords: integrated fruit production, organic farming, agroecology, ecosystem services, agroforestry, climate change, socio-economics

\section{INTRODUCTION}

It is likely during the 1930s that apple was isolated from the traditional multispecies, often agrosilvopastoral, systems to be cultivated in monospecies fruit-tree orchards (e.g., in Europe; Herzog, 1998). Although statistics at the world scale need rigorous analyses and should be taken with caution, with for example a strong decrease of cultivation area from the middle on 1990's onwards (Figure 1a) that is not really consistent with changes in productivity (Figure 1b), some general statements can be made. In past decades, worldwide apple cultivation has undergone a tremendous increase in both cultivation area (from ca. 1.8 million ha in 1961 to ca. 7.7 million ha in 2016) and production (from ca. 17.2 million t in 1961 to ca. 133.8 million $t$ in 2016) (Figure 1a). In the same time range mean productivity has increased from $5.9 \mathrm{t} \mathrm{ha}^{-1}$ to $15.2 \mathrm{t} \mathrm{ha}^{-1}$ (Figure 1b). These progresses are due to both the use of high performance plant material (e.g., breeding for new cultivars with high fruit aesthetic quality and long shelf life; Brown and 
Maloney, 2003) and cultivation techniques through the improvement of the planning, establishment and management of orchards (Robinson, 2003).
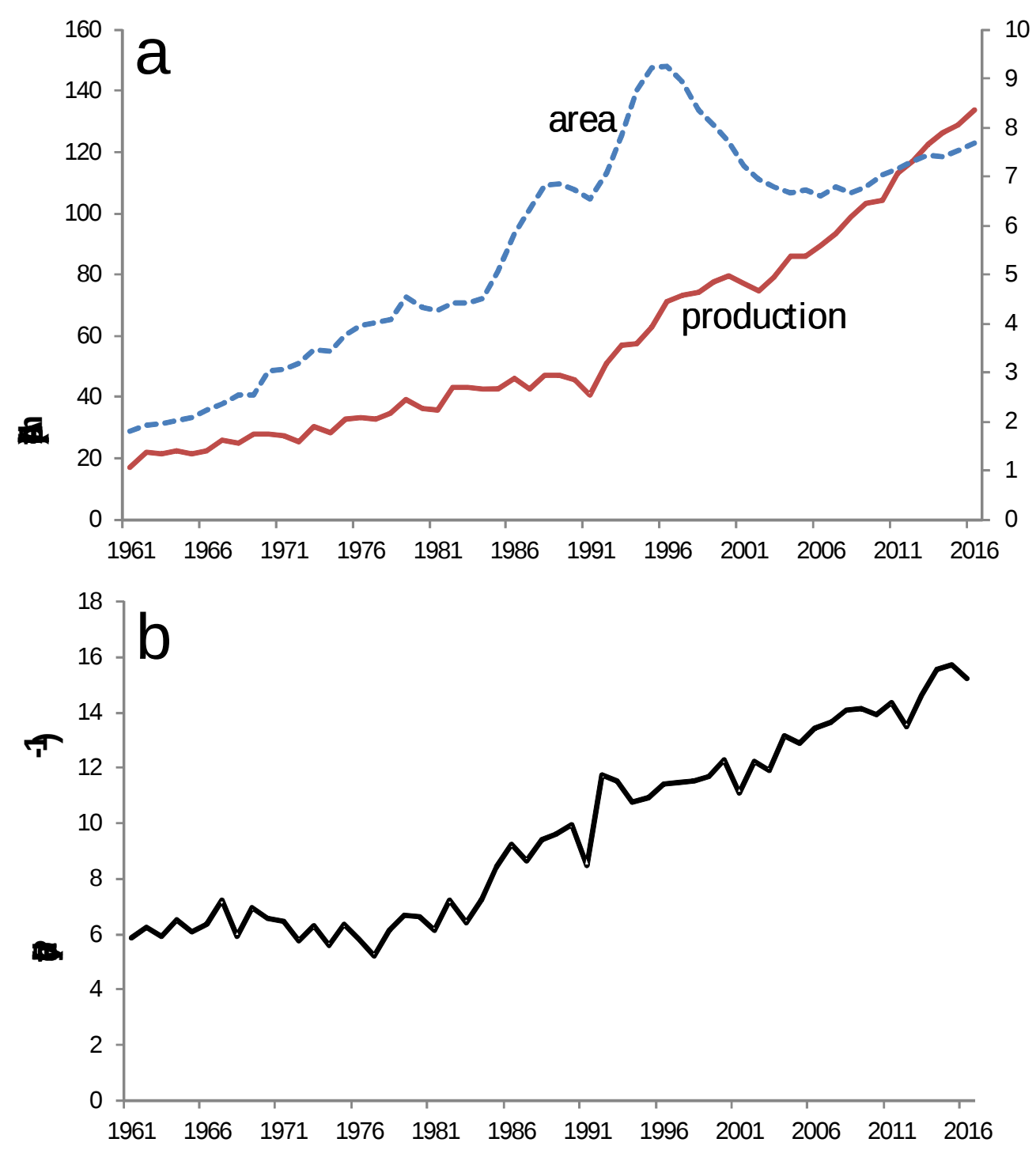

Figure 1. Progress in apple production (million ton) and cultivation area (million ha)(a), and apple productivity ( $\mathrm{t} \mathrm{ha}^{-1}$ )(b) in total world from 1961 to 2016 (FAO, http://www.fao.org/faostat/en/\#data; for 'apple', 'all countries', 'all years', 'area harvested', 'production quantity’ and 'yield’; accessed 29 March, 2018).

However, this intensification of apple cultivation, often coupled with a 'weed-free' (or 'bare-soil') strategy eradicating all vegetation on the orchard floor, was done at the expense of an increasing reliance on pesticides, i.e., herbicides to limit competition for water and nutrients and phytosanitary treatments against pests and diseases, hereafter referred to as 'pests'. This reliance on chemicals with known adverse effects on the environment and human health is considered as the main obstacle to the sustainable intensification of agriculture in general (see for example in China; Lu et al., 2015). Apple remains one of the most treated fruit crop (EWG, 2017). Indeed, in order to achieve high 
yields of high quality fruit apple, orchards require frequent pesticide applications, up to ca. 35 according to a survey made in France in 2012 (MAAF, 2014) and more generally between 10 and 24 according to Granatstein and Peck (2017). Moreover, a strong reduction in the number of cultivars accompanied this intensification increasing the risk of narrowing the genetic ability to resist to or tolerate existing and new pests, and to adapt to climate change. For example, in Germany, it is estimated that the traditional multispecies 'streuobst' systems hosted a high apple genetic diversity with ca. 1400 cultivars which were robust and well adapted to the local pedoclimatic conditions (Herzog, 1998) whereas in the current monocropping system $52 \%$ of apple production is covered by only five cultivars (Garming, 2013). A main conclusion is that current high density monoclonal orchards are hardly appropriate to drastically reduce pesticide use (Simon et al., 2011) and that both the range of existing commercial apple cultivars and the design of the apple orchard system need to be reconsidered (Lauri and Simon, 2018).

In the following we review how initiatives such as 'Integrated Fruit Production', 'Organic Farming', and 'Agroecology' developed in past decades have renewed our way to establish and manage more sustainable systems of apple production. Secondly, taking inspiration from 'Agroforestry' we show that apple-based systems may also be designed including other crops and considering a range of 'ecosystem services'. The need to foster fundamental and applied researches on how the apple tree interacts with its environment will be emphasized.

\section{IMPROVING THE SUSTAINABILITY OF CONVENTIONAL ORCHARDS}

\section{Integrated Fruit Production, Organic Farming and Agroecology}

The idea to meet the global challenges of securing the food supply while reducing external inputs and minimizing negative impacts on the environment and human health were institutionalized in the 1980s (Granatstein and Peck, 2017). A common ground of the several initiatives developed in past decades is the concept of 'sustainability' which was defined as "the ability to make development sustainable to ensure that it meets the needs of the present without compromising the ability of future generations to meet their own needs” (Brundtland, 1987). In this general framework, three main apple farming systems have been developed in past decades that are still co-existing.

Integrated Production (IP) was officially initiated in 1977 under the umbrella of IOBC (International Organisation for Biological and integrated Control) to promote environmentally safe methods of pest control, and later to promote the development and adoption of IP methods (Avilla and Riedl, 2003). Applied to fruit, Integrated Fruit Production (IFP) is defined as "the economical production of high quality fruit, giving priority to ecologically safer methods, minimizing the undesirable side effects and use of agrochemicals, to enhance the safeguards to the environment and human health" (Malavolta and Cross, 2009). Continuous studies have been developed to improve IFP implementation, mainly about Integrated Pest Management (IPM), including the use of biorational pesticides that express selectivity to specific developmental stages (e.g., biopesticides and insect growth regulators), semiochemicals (e.g., sex pheromones) and biological control (using natural enemies of pests) (Damos et al., 2015). In many countries, and also at the international scale through the impetus of institutions such as the 'Food and Agriculture Organization' (FAO), conventional apple orchards have been encouraged to move towards IFP with the objective to minimize synthetic pesticide use (Damos et al., 2015). IFP can then be considered as the standard conventional apple orchard, at least in Europe where IPM is compulsory since 2009 (Damos et al., 2015).

Organic Farming (OF) is defined as a production system that sustains the health of soils, ecosystems and people. It relies on ecological processes, biodiversity and cycles 
adapted to local conditions, rather than on the use of inputs with adverse effects. OF typically puts emphasis on maintenance of soil organic matter via the use of organic composts, mulches and green manures (Neilsen and Neilsen, 2003) and also makes use of nitrogen fixing plants (Weibel and Häseli, 2003). In Europe, OF conforms to strict regulations that define precise farming and processing techniques (Migliorini and Wezel, 2017). A main difference between IFP and OF is that OF aims to manage the orchard system as a whole insisting on the ban of synthetic inputs and their derivatives (Weibel and Häseli, 2003). Organic farming combines "tradition, innovation and science to benefit the shared environment and promote fair relationships and a good quality of life for all involved” (IFOAM, 2005; Niggli et al., 2016). Although the area of apple production in OF is strongly increasing since the past recent years (Granatstein et al., 2016), OF is still currently less developed than IFP with around 10\% of the fruit-growing area in the main fruit production regions in Europe (Kienzle and Kelderer, 2017).

Agroecology (AE) combines knowledge in agronomy and ecology and has a defined set of principles for the ecological management of agrifood systems which extends what is developed in OF integrating the more general concept of 'ecosystem services' (see below) and especially socio-economic and political principles that are not or less explicitly managed in IFP and OF (Gomez et al., 2016; Migliorini and Wezel, 2017). Agroecology meets an increasing interest in apple production since it opens routes to design novel apple-based systems optimizing interactions between the apple tree and the other plants of the system (Simon et al., 2017). Although many cultivation practices are similar for IFP, OF and AE (e.g., choice of species and genotypes to optimize positive interactions and minimize negative interactions among them; management of soil structure and fertility; pest and weed management), the origin and quantity of products used and also often the design of the system, are different (Migliorini and Wezel, 2017).

To summarize, if the use of synthetic products differentiates IFP and OF, without a clear position of AE on this aspect, these latter two farming systems share a common holistic view towards improving the sustainability of the apple systems based on more knowledge on, and a better use of, interactions among plants, and between plants and the environment. Using the grid established by Hill (1998) to compare the various degrees of sustainability of agroecosystems, IFP would conform essentially to the 'efficiency' (i.e., improving the use of a given chemical input) and 'substitution' (i.e., replacing one input by another one or by another technique that is less disruptive) strategies. On the other hand, OF and even more AE are more in the 'redesign' strategy (e.g., with various spatial and temporal combinations of plant species around the apple) and management of the whole system at both agricultural practices and socioeconomic levels. However, apart from the restriction on synthetic pesticides use specific to OF, practices (e.g., choice of associated plants, cultural operations) developed in IFP, OF and AE systems may have converged over time especially under the increasing constraints due to international or national regulations relative to the use of phytosanitary products.

\section{Setting innovative apple orchards. Example of initiatives reducing pesticide use}

Simon et al. (2011) compared the level of use of fongicides and insecticides, and agri-environmental performances of three farming systems, 'national IFP standards', in short 'IFP', 'low-input' (i.e., pesticide use as a last resort) and OF. The study also included the effect of the cultivar using three cultivars differing in scab susceptibility: 'Ariane' (Vf-resistant), 'Melrose' (low-susceptibility) and 'Golden Delicious' (susceptible). A significant farming system-cultivar interaction effect was found. Indeed, 
as hypothesized, the highest pesticide use was found for 'Golden Delicious' especially in IFP system. The least pesticide use ( -43 to $-56 \%$ compared to 'Golden Delicious') was found in 'Ariane' and 'Melrose' in both low-input and OF. However, considering yield and fruit damages, only 'low-input' 'Melrose' and 'low-input' 'Ariane' systems achieved similar results as the same cultivars in IFP. These results indicated that the choice of the cultivars according to their genetic resistance or tolerance to pests has a crucial role when implementing low pesticide systems.

Within a given farming system, the system design also plays a significant role in pest dissemination. For example, working on the apple-scab pathosystem without fungicides, and mixing a susceptible cultivar and a resistant cultivar in equal proportions, Didelot et al. (2007) observed a significant reduction in disease incidence over both study years $(-7.3$ to $-21.3 \%)$, and severity in the second year $(-35.4 \%)$ in the within-row mixtures, compared to the monoculture of the susceptible cultivar. Moreover, combining within-row mixture and a moderate fungicide treatment, disease incidence was reduced by $75.1 \%$ on leaves and by $69.7 \%$ on fruits. Going further and although not really applicable in practice, the modeling work developed by Sapoukhina et al. (2007) showed that random patterning of susceptible and resistant apple cultivars can reduce pathogen infection.

All together, these works indicate that, in a monospecies orchard, both the intrinsic tolerance or resistance of apple cultivars to pest and planting design can be combined to significantly reduce pest damages and/or at least permits reducing pesticide treatments. However, all these systems whether IFP, OF or AE are still dependent on regular and tightly adjusted inputs in terms of cultural operations and treatments. Improving apple cultivation sustainability needs revisiting actual concepts of apple cultivation, especially on two aspects that are developed in the following chapter, plant diversity 'around' the apple and plant arrangement.

\section{REDESIGNING MORE DIVERSIFIED AND MULTIFUNCTIONAL APPLE- BASED SYSTEMS}

\section{The concept of ecosystem service}

The Millennium Ecosystem Assessment (2005) and more recently the Common International Classification of 'ecosystem services' (CICES; Haines-Young and Potschin, 2018) consider that a natural ecosystem or an anthropized ecosystem, i.e., an agroecosystem, can provide various 'services' defined as "the benefits people obtain from ecosystems” (Millennium Ecosystem Assessment, 2005). Typically, a conventional apple farming system aims at providing quite only a 'provisioning service', namely apple production. However, considering more complex systems such as OF and AE, there is a shift from a monofunctionality to a multifunctionality of the orchard. This multifunctionality may be handled using the ecological concepts of 'ecosystem services' (Barot et al., 2017). Other services may be considered beside production: 'regulation' (e.g., regulation of pests through the mixing of genotypes or nutrient cycling through the use of nitrogen-fixing grass in the alley) and/or 'cultural' (e.g., 'pick-your own' orchards). More precisely, Demestihas et al. (2017) identified five services that, apart from fruit production, can be provided to a satisfying level by an apple farming system: climate regulation, soil nitrogen availability, water regulation, pest and disease control, and pollination. These services can be optimized through the choice of plant material and agricultural practices. Both aspects can be optimized via the design of 'agroecological 
infrastructures' that include not only the management of the inter-row flower or grass strips but also the hedgerows composed of bushes and trees around the plot. The objective of these agroecological infrastructures is to host beneficial arthropods by providing food complements such as nectar, pollen and/or honeydew for optimal survival, fitness and fecundity (Simon et al., 2010; Albert et al., 2017; Demestihas et al., 2017; Simon et al., 2017).

Scarce studies have been developed on ecosystem services in apple orchards and especially on interdependencies between them, and their relations with the environment and cultural operations. Recently, Demestihas et al. (2018) modeled several ecosystem services (soil nitrogen availability, climate regulation, water cycle maintenance and regulation, and fruit production) at the annual scale and interactions between some of them. For example, considering apple production and denitrification, they showed that a weak crop reduces nitrogen needs and thus nitrogen absorption by the trees, therefore increasing nitrogen leaching.

\section{Implementing ecosystem services in apple-based farming systems: combining plant diversity and plant arrangement}

\section{Increasing plant diversity.}

As seen above plant diversity is a main issue in OF and AE because it is the combination of the various plant species, whether annuals or perennials, grass, bush or even trees, that is the basis of ecosystem services provided by the system. Indeed, plant diversity is at the core of the three main classes of ecosystem services identified in all OF and AE systems (Migliorini and Wezel, 2017) and especially in apple-based OF and AE systems (Demestihas et al., 2017, 2018; Simon et al., 2017), namely, provisioning, regulation and cultural.

There is a consensus that functional differences among species are more important for biodiversity effects than species richness per se. This means that it is important to identify precisely the traits of the species (their 'functional characteristics') one wants to introduce in the system and the way they can be managed, e.g., soil cover, nitrogen fixing, host for natural enemies (Bakker et al., 2018). Several species can share a given functional trait and in this case the choice of only one of these species may be sufficient. For example, considering soil nitrogen availability, biological nitrogen fixation can be provided using various legumes such as white clover (Trifolium repens) but also alfalfa (Medicago sativa) or sainfoin (Onobrychis viciifolia) and the choice of one of those species depends more on the will to grow an annual or a perennial grass cover in relation to technical and economic considerations, and pedoclimatic conditions. However, some redundancy may be useful to face disruptions caused by climatic events (Duru et al., 2015). For example, pest control often relies on a range of resources in the agroecosystem, e.g., plant assemblages providing natural enemies with resources and habitat all year long (Simon et al., 2010) or 'banker plants' that serve as alternative hosts for a parasitoid or predator of the target crop pest (Demestihas et al., 2017). Plant diversity also needs to be considered in interaction with management even though a given practice can have various effects on pest dissemination depending on the period of the year, and above all the presence of alternative resources. For example, codling moth sentinel egg predation in apple canopy mainly due to the earwig Forficula pubescens is 
significantly higher in alleys with tall grass than in frequently mowed alleys maintaining short grass in June, but the opposite was observed in July when alternative food was available in the tall grass (Marliac et al., 2015).

Apart from the provisioning and the regulation services, plant diversity in the apple-based system also provides cultural services, consisting for example in the heritage value of some endemic or cultivated plants grown in the orchard and its surroundings, or from another point of view the enjoyment of 'pick your own' activities for families, not only of apple but also of other fruits or aromatic plants, especially around large cities.

\section{Plant arrangement: insights into the structural and temporal dimensions.}

Plant diversity needs to be considered along with the spatial arrangement, and the within-time and within-space interactions have to be considered in the design and the decisional system (Simon et al., 2017). In typical OF and AE where apple production is the main production, apple trees are planted in rows and the agroecological infrastructures and agricultural practices are mainly devoted to pest regulation (e.g., Albert et al., 2017) and soil nitrogen availability (Demestihas et al., 2017). However, apple trees can also be grown with plants providing other production such as soft-fruits, vegetables and aromatic plants that can be combined with plants providing pest control and/or soil nitrogen availability services (e.g., 'verger maraîcher' in France, GRAB, 2017; 'silvoarable agroforestry' in UK, Smith et al., 2016). Moreover, such diversity also enables to design 'pest suppressive' agroecosystems (i.e., highly unfavourable to pests and highly favourable to their natural enemies) through barrier-dilution effects, push-pull processes with trap and repulsive plants, and avoidance strategies beside conservation biocontrol.

In typical $\mathrm{OF}$ and $\mathrm{AE}$, apple-trees are in most cases at the higher stratum, i.e., in full sun whereas all the other plants, as bush or grass, occupy the lower strata below apple trees. However, more complex systems may combine plants in various strata: large trees (e.g., nut and timber trees) over-topping the apple, with shrubs (e.g., black currant) and possibly annuals (e.g., corn-soybean rotation) in the understory. These systems are identified as 'multifunctional woody polycultures' (Lovell et al., 2017). They resemble traditional 'agrisylvicultural systems', and also 'agrosilvopastoral systems' (Parrotta et al., 2015) when they combine grazing sheeps or chickens that can eat fallen leaves possibly infected by scab and pest arthropod larvae on the ground (Burgess et al., 2017; Corroyer and Upson, 2015; McAdam and Ward, 2018). These systems belong to 'agroforestry' that is a contraction of the terms "agriculture and forestry and designates land use that combines aspects of both, including the agricultural use of trees" (van Noordwijk et al., 2016). Fruit trees are the primary driver of agroforestry adoption worldwide especially in the tropics (Wolz and Delucia, 2018) and are considered as high value for agroforestry (den Herder et al., 2017; Pantera et al., 2018; Lauri et al., 2019).

Agroforestry and agroecology are two approaches of complex multifunctional systems, with agroforestry including explicitly woody plants. It is worth noticing that agroforestry is not mentioned in the European regulations and IFOAM (2005) norms concerning crop production practices in OF and AE (Migliorini and Wezel, 2017). However, it is considered that agroforestry offers a relevant framework for agroecological practices (Wezel et al., 2014). Although agroforestry considers mainly the structural and temporal arrangement of the system associated to different uses (e.g., in the USA: alley cropping, silvopasture, riparian buffers, windbreaks and forest farming; Wilson and Lovell, 2016), agroecology clearly addresses the ecological-driven functioning of the system (Wezel et al., 2014). It should also be mentioned that agroforestry systems have no 
guidelines about pesticide use even though those systems are "less reliant... on the use of synthetic pesticides” compared to simplified and specialized cropping systems (UCDAVIS Agricultural Sustainability Institute, 2018) (Figure 2).

Designing 'Apple-Tree based AgroForestry Systems' (AT-AFS) that would include the apple in a multistrata system complementing apple production with other productions (other fruits, vegetables, aromatic plants; animals) and providing other services such as those already included in OF and AE, is challenging. Some indications on the spatial arrangement of such complex systems already exist in literature. For example, although OF and AE may keep on planting distances usual for IFP, i.e., $3.5 \mathrm{~m}$ to $6 \mathrm{~m}$ between tree rows and 1 to $4 \mathrm{~m}$ between trees within the row, depending on the cultivar-rootstock combination (Smith et al., 2016), 'multifunctional woody polycultures' have larger distances with ca. $9 \mathrm{~m}$ and ca. $4 \mathrm{~m}$ between rows and within the row, respectively (Lovell et al., 2017).

\section{Potential advantages of Apple-Tree based AgroForestry Systems.}

A main economic interest of OF, AE and further AT-AFS would be to optimize the global productivity per land area but it has to consider the fact that not all productions are at the same pace. For example in an AT-AFS that would combine apple and timber trees, apple production is at the annual pace whereas timber is only valorized after 20 to 50 years. Such improvement in area productivity is all the more true if there is deep and rich soil and complementarity in vegetation cycle. This is typically the case for an agroforestry system combining winter wheat harvested at the end of spring and walnut with late budburst thus with a little overlapping in the growing cycles. Various metrics exist to evaluate the performance of multiproduction systems, among which the Land Equivalent Ratio (LER) is the most known (Lovell et al., 2017). LER compares yields of crops grown together to crops grown as pure stands. For example for a system with two species: $\mathrm{LER}=($ mixed yield A/pure yield A) + (mixed yield B/pure yield B). 


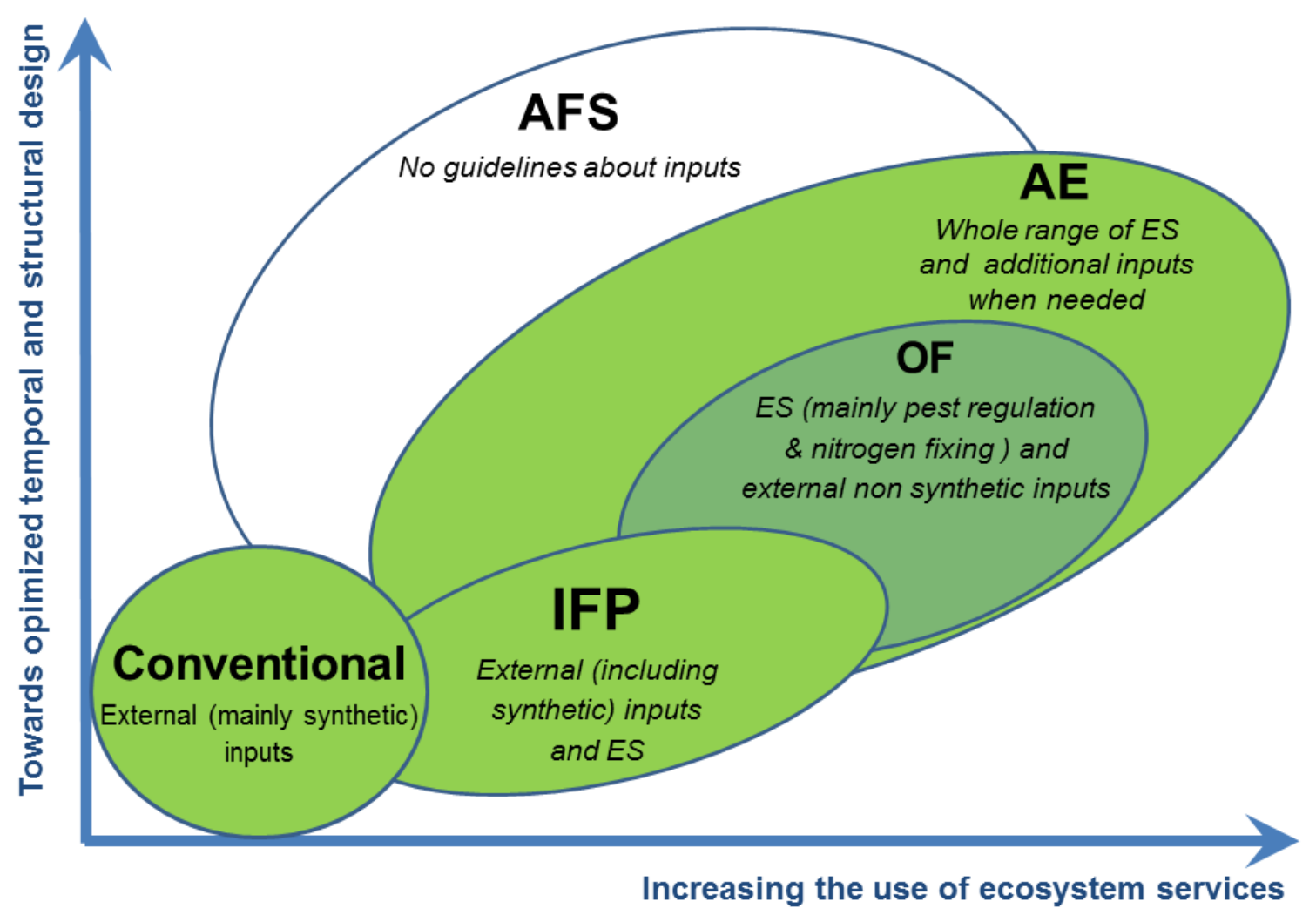

Figure 2. Sorting apple agroecosystems according to the use of ecosystem services (ES) and the optimization of temporal and structural design. The horizontal axis renders, from left to right, the progressive use of ES. The conventional orchard typically relies on the use of external (mainly synthetic) inputs whereas Integrated Fruit Production (IFP) aims to efficiently manage those synthetic inputs with the possible use of some ES and alternative methods. Organic Farming (OF) includes the use of some ES, mainly natural pest regulation and nitrogen fixing by plants, and no use of external synthetic inputs. Agroecology (AE) manages the whole range of ES (see text) with a better emphasis on societal needs. OF may be considered as fully included in AE. The vertical axis renders, from bottom to top, the improvement of the structural and temporal design of the system taking advantage of concepts developed in agroforestry. There are no guidelines about inputs in agroforestry systems (AFS).

Although, to the best of our knowledge no statistics exist for AT-AFS, the LER of a cherry-walnut-annual intercrop (sunflower, durum wheat, barley, oilseed rape) agroforestry system is close to 1.3, i.e., 1 ha of cherry-walnut-annual intercrop agroforestry may produce as much 1.3 ha of cherry, walnut and annual intercrop in separated stands due to fact that cherry and annual intercrop grow in the inter-row of walnut that is otherwise not used, even if in the combined system the inter-row of walnut is a little larger than in pure walnut stand (Dupraz et al., 2005). Beyond this global economic interest that can be valorized only in the long term, depending on the species production, AT-AFS should also ensure more stable economic returns over the years because it is based on various plant productions (e.g., vegetables; GRAB, 2017) and 
possibly animals such as poultry or sheep (see above) provided the apple tree shape is redesigned or the presence of sheep in the orchard is restricted from fall to spring before trees begin to grow (Lauri et al., 2019).

\section{GOING FORWARD: RESEARCH ROUTES FOR THE FUTURE}

Most of our knowledge in apple tree architecture and physiology has been developed removing as much as possible influences of the global biotic and abiotic environment. When external variables (temperature, irrigation, nutrition...) are considered in these studies they are generally well focused and research seldom considers combination of variables for obvious reasons of complexity. These research works are well adapted to the setting of conventional apple orchards whose performance is tightly related to the good integration of all the components of the 'orchard system puzzle', namely the plant material (rootstock, tree quality), the system design (tree arrangement and density, support system) and cultural operations (tree training and pruning, irrigation, fertilization) (Barritt, 1992).

Designing apple OF, AE or AT-AFS, needs more research on both plant-plant and plant-environment (biotic and abiotic) interactions. The ecological science already provides some main concepts, such as the 'competition-facilitation' framework (e.g., interactions between trees or shrubs and grass; Scholes and Archer, 1997) that now need to be better applied in the field of apple diversified systems. From the 'plant science' point of view we need more knowledge on the plasticity of plant architecture and ecophysiology in response to the more complex biotic and abiotic environment.

\section{Belowground niche partitioning.}

The interest of multispecies systems was already promoted by Gliessman (1985) considering that although multiple cropping systems "use more water, they are able to obtain water not available to monoculture", and therefore "they use the water more efficiently, and contribute significantly to soil conservation”. These multispecies systems therefore demonstrate the further potential for their more widespread use. More generally, interactions at the belowground level need more detailed studies. The positive effects of legumes as groundcover in the inter-row alleys (e.g., white and red clover, Trifolium repens L. and Trifolium pratense L., respectively, or alfalfa, Medicago sativa L.) are well known for their contribution to soil nitrogen (Merwin, 2003). This typically illustrates the facilitation process where the root systems of the various species explore a same soil layer. However, several lines of evidence would show that an aboveground multistrata system is also mirrored, even to a lesser extent, by multilayer root systems with annuals being mostly in the top soil and trees having deeper rooting. For example, in an experiment on walnut-winter cereals, Cardinael et al. (2015) show that competition induces deeper rooting of the trees keeping the perennial grass or annuals in the top soil horizon. Nevertheless, most of these studies are realized without irrigation supply in either wetlands or drylands. In these conditions, hydraulic redistribution (HR) has been measured from moist to drier portions of the soil (Domec et al., 2010) but also from soil to roots and from roots to soil and among overstory trees and understory shrubs and grasses (Barron-Gafford et al., 2017). To what extent HR is maintained in the context of an irrigated apple system needs to be reconsidered. First, root distribution is highly opportunistic being concentrated in the wetted zones determined by the irrigation type and scheduling (Sokalska et al., 2009) raising the question of the compatibility between localized irrigation and the maintenance of root layering. Second, root distribution in the 
soil is dynamic depending on tree and grass age (Scholes and Archer, 1997) possibly related to changes in tree root architecture between the young and the mature stages of the tree (e.g., in peach, secondary vertical roots do not develop before the second year in a peach-grass system with regulated deficit irrigation; Forey et al., 2017). According to Demestihas et al. (2017) working on an apple mixed with cover crops orchard, such optimal belowground niche partitioning could be a way to decrease the loss of water and also nutrient leaching to the water table.

\section{Growing apple in the shade of over-topping trees.}

The possibility to grow apple trees with other, possibly over-topping, trees remains to be explored. In hot and dry summer climate, typically in the Mediterranean type climate, apple trees may be subjected to an excess of solar radiation during the summer months with known deleterious effects on fruit quality (sunburn) and leaf functioning (photooxydative damage) (Correlli-Grappadelli and Lakso, 2007; Racsko and Schrader, 2012). This issue is managed using shade nets, also used as hail nets, that reduce light quantity and may also change light quality with known effects on fruit coloring (Mupambi et al., 2018). To what extent 'shade trees' may be used instead of shade nets to mitigate climate extremes (heat, light, precipitation) effects on apple, especially in the context of climate change, remains to be studied especially regarding both distances between overstory trees and apple trees and the proper pruning of the overstory trees to ensure that sufficient light reaches the apple trees. Further research in apple may take lessons from the increasing amount of works developed in the tropics on two fruit trees, cocoa and coffee, known as shade-adapted species and that are traditionally cultivated in multistrata systems. Research on architecture and ecophysiology (Tscharntke et al., 2011; Padovan et al., 2018) and plant-pest interactions (Andres et al., 2016) in cocoa and coffee also documents the agronomic and economic issues related to fruit-tree growing in agroforestry systems. Preliminary results obtained in our experimental AT-AFS at INRA Montpellier ('GAFA' project; Pitchers et al., this symposium) indicate that apples trees planted at $6.5 \mathrm{~m}$ from walnut trees beneficiate from a gap fraction (fraction of view that is unobstructed by walnut canopy, leaves and branches, in any particular direction) of ca. $70 \%$. This value is close to the reduced photosynthetic active radiation usually measured under hail nets, i.e., 32.8\%, without altering air temperature, humidity or rainfall, and slightly increasing yield (e.g., apple, Bosco et al., 2018).

\section{Adapting apple plant material and optimizing training and pruning.}

Once the whole system is designed, including structural (spatial arrangements in horizontal and vertical dimensions) and temporal aspects (e.g., simultaneous vs. delayed plantation of the various species), the choice of the rootstock and cultivar and the training and pruning of the apple trees are crucial. Semi-vigorous or high-vigor rootstocks from the Malling Merton series (Ferree, 1988) or from the Cornell-Geneva series (Lordan et al., 2017; Fazio, 2017) for example, should be recommended to improve anchoring in the soil, and nutrients and water absorption in a context of above and belowground competition. This choice also needs to consider the resistance or tolerance to some major pests and diseases such as fire blight caused by Erwinia amylovora, crown and root rot caused by Phytophtora cactorum, and also replant disease complexes (Fazio, 2017). The use of own-rooted trees with high vigor (Maguylo and Lauri, 2007) could also be evaluated in these contexts. After plantation, training and pruning procedures also need to be well adapted to a reduced light climate. Research developed in past decades in tree 
architecture management clearly indicates the importance of increasing canopy porosity to air and light through precision pruning, for example using 'artificial extinction' (Lauri et al., 2004; Willaume et al., 2004; Lauri and Corelli-Grappadelli, 2014) with beneficial effects on fruit size and return-bloom (Lauri et al., 2007; Tustin et al., 2012; Breen et al., 2014, 2015, 2016; Tustin and van Hooijdonk, 2016) and partly on pest reduction (Simon et al., 2006). However, overstory canopy also needs to be managed and partial pollarding of trees can both provide fodder, fuelwood or woodchips as a provisioning service, and improve light transmission to the understory especially the apple tree as a regulation service (Le Bec et al., 2016).

\section{Developing links with socioeconomics to optimize the market chain.}

Eventually, the socioeconomic impact of such diversified systems also needs to be assessed. As mentioned by Smith et al. (2016) in concluding remarks on two apple case studies, agroforestry seemed to have benefits in terms of reducing pest levels if apple cultivars are resistant or tolerant to major pests. It "could work well in a diverse, potentially small-scale system such as a market garden, where apples could contribute to direct marketing channels such as vegetable box schemes or farm shops” (Smith et al., 2016). Those agroforestry systems are recent, and existing and up-coming systems are to be considered and studied as well as the agrifood system they participate in (GRAB, 2017).

\section{CONCLUSIONS}

As for the 'industrial agriculture' in general (Struik and Kuyper, 2017) conventional apple orchard, characterized by high level of regular inputs (water, nutrients, pesticides, mechanization), is likely to remain the dominant source of apple supply as far as external resources are kept at a rather low price and negative externalities on the environment and human health are not considered. However, such a production system cannot be sustainable in the long term and/or in all production regions in the world especially due to its dependence on non-renewable energy and also its negative long-term impacts on human health and environment. Moving towards more self-regulating, environment-friendly apple production systems, as already engaged in the last decades with IFP, OF and more recently AE, offers promising opportunities. The idea to manage more efficiently the structural and temporal design of these complex systems under the paradigm of AT-AFS may be considered as another step in the same dynamics (Figure 2). It emphasizes the interest to diversify short term and long term productions of apple and other products, to design more 'pest suppressive' and 'nitrogen-autonomous' agroecosystem and also to better explore the climate mitigation offered by the multistrata design of the system.

Implementing such systems needs more knowledge from the analytical side on how plants interact among them and with the environment with regard to access to aboveand belowground resources. It also requires more interdisciplinary approaches gathering horticultural science (e.g., yield performance of apple in reduced light climate) and ecology including chemical ecology (e.g., volatile organic compounds, VOC) and landscape ecology (e.g., effects of landscape heterogeneity on pests dissemination). So far, we lack references on complex apple-based agroecosystems, because traditional systems have almost disappeared except in few sites (e.g., cider apple orchards in Brittany, France). We make a plea for more participatory research involving growers, technicians, researchers and stakeholders in the market chain to strengthen the "economic, 
biodiversity, resource protection and social values of orchards” (Robertson et al., 2012) with practical outputs combining scientific and empirical knowledge.

\section{Literature cited}

Albert, L., Franck, P., Gilles, Y. and Plantegenest, M. (2017). Impact of Agroecological Infrastructures on the Dynamics of Dysaphis plantaginea (Hemiptera: Aphididae) and Its Natural Enemies in Apple Orchards in Northwestern France. Environmental Entomology 46, 528-537. https://doi.org/10.1093/ee/nvx054

Andres, C., Comoé, H., Beerli, A., Schneider, M., Rist, S. and Jacobi, J. (2016). Cocoa in Monoculture and Dynamic Agroforestry. Chapter 3. In: Sustainable Agriculture Reviews, E. Lichtfouse, ed., 19, p.121-153. DOI 10.1007/978-3319-26777-7_3

Avilla, J. and Riedl, H. (2003). Integrated Fruit Production for Apples - Principles and Guidelines. In: Apples - Botany, Production and Uses, D.C. Ferree and I.J. Warrington, eds., CABI Publishing, Wallingford, Cambridge, UK, p. 539-550.

Bakker, L.M., Mommer, L. and van Ruijven, J. (2018). Can root trait diversity explain complementarity effects in a grassland biodiversity experiment? Journal of Plant Ecology 11(1), 73-84.

Barot, S., Allard, V., Cantarel, A., Enjalbert, J., Gauffreteau, A., Goldringer, I., Lata, J.C., Le Roux, X., Niboyet, A. and Porcher, E. (2017). Designing mixtures of varieties for multifunctional agriculture with the help of ecology. A review. Agronomy for Sustainable Development 37: 13. DOI 10.1007/s13593-017-0418-x

Barritt, B.H. (1992). Intensive orchard management. Good Fruit Grower, Washington State Fruit Commission. Yakima, Washington, USA.

Barron-Gafford, G., Sanchez-Cañete, E.P., Minor, R.L., Hendryx, S. M., Lee, E., Sutter, L.F., Tran, N., Parra, E., Colella, T., Murphy, P.C., Hamerlynck, E.P., Kumar, P. and Scott, R.L. (2017). Impacts of hydraulic redistribution on grass-tree competition vs facilitation in a semi-arid savanna. New Phytologist 215, 1451-1461.

Bosco, L.C., Bergamaschi, H., Cardoso, L.S., Aires de Paula, V., Marodin, G.A.B., and Brauner, P.C. (2018). Microclimate alterations caused by agricultural hail net coverage and effects on apple tree yield in subtropical climate of Southern Brazil. Bragantia 77(1). http://dx.doi.org/10.1590/1678-4499.2016459

Breen, K.C., van Hooijdonk, B.M., Tustin, D.S., Wilkie, J.D., Bound, S.A., Middleton, S.G. and Close, D.C. (2014). Changes in fruit set of 'Gala' apple in response to environment and artificial spur extinction. Acta Horticulturae 1058, 77-83.

Breen, K.C., Tustin, D.S., Palmer, J.W. and Close, D.C. (2015). Method of manipulating floral bud density affects fruit set responses and productivity in apple. Scientia Horticulturae 197, 244-253.

Breen, K.C., Palmer, J., Tustin, D.S. and Close, D.C. (2016). Artificial spur extinction alters light interception by 'Royal Gala’ apple trees. Acta Horticulturae 1130, 265-272.

Brundtland, G.H. (chairman). (1987). Our Common Future. Report of the world commission on environment and development. http://www.un-documents.net/our-common-future.pdf.

Brown, S.K. and Maloney, K.E. (2003), 'Genetic Improvement of Apple: Breeding, Markers, Mapping and Biotechnology’, In: Apples - Botany, Production and Uses, D.C. Ferree and I.J. Warrington, eds., CABI Publishing, Wallingford, Cambridge, UK, p. 31-60.

Burgess, P.J., Chinery, F., Eriksson, G., Pershagen, E., Pérez-Casenave, C., Lopez Bernal, A., Upson, A., Garcia de Jalon, S., Giannitsopoulos, M. and Graves, A. (2017). Lessons learnt - Grazed orchards in England and Wales', AGFORWARD project. http://www.agforward.eu/index.php/en/Grazed_Orchards.html/. (Last access 12 January 2018).

Cardinael, R., Mao, Z., Prieto, I., Stokes, A., Dupraz, C., Kim, J.H. and Jourdan, C. (2015). Competition with winter crops induces deeper rooting of walnut trees in aMediterranean alley cropping agroforestry system. Plant Soil, 391, 219-235.

Correlli-Grappadelli, L. and Lakso, A.N. (2007). Is Maximizing Orchard Light interception Always the Best Choice? Acta Horticulturae 732, 507-518.

Corroyer, N. and Upson, M. (2015). Research and Development protocol for Grazed Orchards in France, http://www.agforward.eu/index.php/en/grazed-orchards-in-france.html/ (Last access 22 December 2017).

Damos, P., Escudero Colomar, L.A. and Ioriatti, C. (2015). Integrated Fruit Production and Pest Management in Europe: The Apple Case Study and How Far We Are From the Original Concept?, Insects 6(3), 626-657. 
Demestihas, C., Plénet, D., Génard, M., Raynal, C. and Lescourret, F. (2017). Ecosystem services in orchards. A review. Agronomy for Sustainable Development 37:12, DOI 10.1007/s13593-017-0422-1.

Demestihas, C., Plénet, D., Génard, M., Garcia de Cortazar-Atauri, I., Launay, M., Ripoche, D., Beaudoin, N., Simon, S., Charreyron, M., Raynal, C. and Lescourret, F. (2018). Analyzing ecosystem services in apple orchards using the STICS model. European Journal of Agronomy 94, 108-119.

den Herder, M., Moreno, G., Mosquera-Losada, R.M., Palma, J.H.N., Sidiropoulou, A., Santiago Freijanes, J. J., CrousDurand, J., Paulo, J.A., Tomé, M., Pantera, A., Papanastasis, V.P., Mantzanase, K., Pachana, P., Papadopoulos, A., Plieninger, T. and Burgess, P.J. (2017). Current extent and stratification of agroforestry in the European Union, Agriculture, Ecosystems and Environment 241, 121-132.

Didelot, F., Brun, L. and Parisi, L. (2007). 'Effects of cultivar mixtures on scab control in apple orchards'. Plant Pathology, 56, 1014-1022.

Domec, J.C., King, J.S., Noormets, A., Treasure, E., Gavazzi, M.J., Sun, G. and McNulty, S.G. (2010). Hydraulic redistribution of soil water by roots affects whole-stand evapotranspiration and net ecosystem carbon exchange. New Phytologist 187, 171-183.

Dupraz, C., Burgess, P., Gavaland, A., Graves, A., Herzog, F., et al. eds. (2005). Synthesis of the Sylvoarable Agroforestry for Europe (SAFE) project. INRA UMR System, Montpellier, France. http://www1.montpellier.inra. fr/safe/english/results/final-report/SAFEFinalSynthesisReport.pdf)(Last access 15 August 2017).

Duru, M., Therond, O., Martin, G., Martin-Clouaire, R., Magne, M.A., Justes, É., Journet, É.P., Aubertot, J.N., Savary, S., Bergez, J. É. and Sarthou, J.P. (2015). How to implement biodiversity-based agriculture to enhance ecosystem services: a review. Agronomy for Sustainable Development 35(4), 1259-1281.

EWG ('Environmental Working Group’) .(2017). A Few Bad Apples...- Pesticides in Your Produce. Why Supermarkets should 'Test and Tell'. https://static.ewg.org/pdf/AFewBadApples.pdf? ga=2.23191802.1123279716.1519715642780402501.1519715642 (Last access 26 February 2018).

Fazio, G. (2017). Evaluating and improving rootstocks for apple cultivation. In: Achieving sustainable cultivation of apple, K. Evans, ed., Burleigh dodds Science Publishing, Cambridge, UK, p.135-164.

Ferree, D.C. (1988). Role of Rootstocks and Spur-type Scions for Controlling Vegetative Growth of Apple and Peach Trees. HortScience 23(3), 464-467.

Forey, O., Temani, F., Wery, J., Jourdan, C. and Metay, A. (2017). Effect of combined deficit irrigation and grass competition at plantation on peach tree root distribution. European Journal of Agronomy 91, 16-24.

Garming, H. (2013). Apple production in Germany. http://www.agribenchmark.org/ comvosfilelist/219/ (Last access 26 February 2018).

Gliessman, S.R. (1985). Chapter 5 - Multiple Cropping Systems: A Basis for Developing an Alternative Agriculture. In Innovative Biological Technologies for Lesser Developed Countries - Workshop proceedings, Washington, D.C., OTA, p. 69-83.

Gómez, L.F., Ríos-Osorio, L.A. and Eschenhagen-Durán, M.L. (2016). Key concepts of agroecology science. A systematic review. Tropical and Subtropical Agroecosystems 19, 109- 117.

GRAB (Groupement de Recherche en Agriculture Biologique). (2017). Associer légumes et arbres fruitiers en agroforesterie. http://www.grab.fr/wp-content/uploads/2017/09/guide verger-maraicher smart GRAB web-1.pdf (Last access 26 February 2018).

Granatstein, D., Kirby, E., Ostenson, H. and Willer, H. (2016). Global situation for organic tree fruits. Scientia Horticulturae 208, 3-12.

Granatstein, D. and Peck. G. (2017). Assessing the environmental impact and sustainability of apple cultivation. In: Achieving sustainable cultivation of apple, K. Evans, ed., Burleigh dodds Science Publishing, Cambridge, UK, p. 524549.

Haines-Young, R. and Potschin M.B. (2018). Common International Classification of Ecosystem Services (CICES) V5.1 and Guidance on the Application of the Revised Structure. http://www.cices.eu (Last access 26 February 2018).

Herzog, F. (1998). Streuobst: a traditional agroforestry system as a model for agroforestry development in temperate Europe. Agroforest. Syst. 42, 61-80.

Hill, S.B. (1998). Redesigning Agroecosystems for Environmental Sustainability: A Deep Systems Approach. Systems Research and Behavioral Science 15, 391-402.

IFOAM (International Federation of Organic Agriculture Movements). (2005). https://www.ifoam.bio (Last access 26 February 2018). 
Kienzle, J. and Kelderer, M. (2017). Growing organic apples in Europe. In: Evans, K. ed., Achieving sustainable cultivation of apple. Burleigh dodds Science Publishing, Cambridge, UK, p. 551-577.

Lauri, P.É., Willaume, M., Larrive, G. and Lespinasse, J.M. (2004). The concept of centrifugal training in apple aimed at optimizing the relationship between growth and fruiting. Acta Horticulturae 636, 35-42.

Lauri, P.É., Crété, X., and Ferré, G. (2007). Centrifugal training in apple - Appraisal of a two-year experiment on cv. 'Galaxy' in southeast France. Acta Horticulturae 732, 391-396.

Lauri, P.É. and Corelli-Grappadelli, L. (2014). Tree architecture, flowering and fruiting. Thoughts on training, pruning and ecophysiology. Acta Horticulturae 1058, 291-298.

Lauri, P.É. and Simon, S. (2018). Advances and challenges in sustainable apple cultivation. In: Achieving sustainable cultivation of temperate zone tree fruits and berries, G Lang, ed., Burleigh dodds Science Publishing Limited, Cambridge, UK, (In press).

Lauri, P.É., Barkaoui, K., Ater, M. and Rosati, A. (2019). Agroforestry for fruit trees in the temperate Europe and dry Mediterranean. In: Agroforestry for sustainable agriculture, M. Mosquera-Losada and R. Prabhu, eds., Burleigh dodds Science Publishing Limited, Cambridge, UK, (In Press).

Le Bec, J., Bailly, A., Brossier, B. and Dupraz, C. (2016). Trunk-Crown growth tradeoff in pollarded trees: influence on wood production. In: Proceedings of the 3rd European Agroforestry Conference. Montpellier, France. Gosme M et al., eds., May 2016. ISBN: 978-2-87614-717-1. EAN: 9782876147171. pp. 111-113. https://www.repository.utl.pt/bitstream/10400.5/11690/1/EURAF2016\%20-\%20Book\%20of\%20Abstracts\%20final.pdf (Last access 26 February 2018).

Lordan, J., Fazio, G., Francescatto, P. and Robinson, T. (2017). Effects of apple (Malus $\times$ domestica) rootstocks on scion performance and hormone concentration. Scientia Horticulturae 225, 96-105.

Lovell, S.T., Dupraz, C., Gold, M., Jose, S., Revord, R., Stanek, E. and Wolz, K. (2017). Temperate agroforestry research: considering multifunctional woody polycultures and the design of long-term field trials, Agroforestry Systems, DOI 10.1007/s10457-017-0087-4.

Lu, Y., Chadwick, D., Norsec, D., Powlson, D. and Shi, W. (2015). Sustainable intensification of China's agriculture: the key role of nutrient management and climate change mitigation and adaptation. Agriculture, Ecosystems and Environment 209, 1-4.

MAAF (Ministry of Agriculture, Agrifood and Forest, France). (2014). Enquête pratiques phytosanitaires en arboriculture 2012. Agreste les Dossiers 22, 1-17.

Malavolta, C. and Cross, J.V., eds. (2009). Guidelines for Integrated Production of Pome Fruits. $4^{\text {th }}$ Edition. IOBC Technical/wprs Bulletin, 47.

Maguylo, K. and Lauri, P.É. (2007). Growth and Fruiting Characteristics of Eight Untrained Genotypes Assessed on Both M.9 and Own-Rooted Trees in Southern France. Acta Horticulturae 732, 93-99.

Marliac, G., Simon, S., Mazzia, C., Penvern, S., Lescourret, F., and Capowiez, Y. (2015) Increased grass cover height in the alleys of apple orchards does not promote Cydia pomonella biocontrol. BioControl 60, 805-815.

McAdam, J. and Ward, F. (2018). System report: Grazed Orchards in Northern Ireland, UK. http://www.agforward.eu/index.php/en/grazed-orchards-in-northern-ireland-uk.html/. (Last access 26 February 2018).

Merwin, I.A. (2003). Orchard-floor Management Systems. In: Ferree, D.C. and Warrington, I.J., eds., Apples - Botany, Production and Uses, CABI Publishing, Wallingford, Cambridge, UK, p. 303-318.

Millennium Ecosystem Assessment. (2005). Ecosystems and Human Well-Being: Synthesis, Island Press. https://www.millenniumassessment.org/documents/document.356.aspx.pdf (Last access, 1 March 2018).

Migliorini, P. and Wezel, A. (2017). Converging and diverging principles and practices of organic agriculture regulations and agroecology. A review. Agron. Sustain. Dev. 37:63.

Mupambi, G., Anthony, B.M., Layne D.R., Musacchia, S., Serra, S., Schmidt, T. and Kalcsitsa, L.A. (2018). The influence of protective netting on tree physiology and fruit quality of apple: A review. Scientia Horticulturae 236, 60-72.

Neilsen, G.H. and Neilsen, D. (2003). Nutritional Requirements of Apple. In: Apples - Botany, Production and Uses, D.C. Ferree and I.J. Warrington, eds., CABI Publishing, Wallingford, Cambridge, UK, p. 267-302.

Niggli U., Willer H. and Baker B. P. (2016). A Global Vision and Strategy for Organic Farming Research. TIPI Technology Innovation Platform of IFOAM - Organics International, c/o Research Institute of Organic Agriculture (FiBL), Frick, Switzerland. 
Padovan, M.P., Brook, R.M., Barrios, M., Cruz-Castillo, J.B., Vilchez-Mendoza, S.J., Costa, A.N. and Rapidel, B. (2018). Water loss by transpiration and soil evaporation in coffee shaded by Tabebuia rosea Bertol. and Simarouba glauca dc. compared to unshaded coffee in sub-optimal environmental conditions. Agricultural and Forest Meteorology 248, 1-14.

Pantera A., Burgess, P. J., Mosquera Losada, R., Moreno, G., Lopez-Dıaz, M.L., Corroyer, N., McAdam, J., Rosati, A., Papadopoulos, A.M., Graves, A., Rigueiro Rodriguez, A., Ferreiro-Domınguez, N., Fernandez Lorenzo, J.L., GonzalezHernandez, M.P., Papanastasis, V.P., Mantzanas, K., Van Lerberghe, P. and Malignier, N. (2018). Agroforestry for high value tree systems in Europe, Agroforestry systems. doi: 10.1007/s10457-017-0181-7 (In press)

Parrotta, J.A., Dey de Pryck, J., Darko, O.B., Padoch, C., Powell, B. and Sandbrook, C. (2015). The Historical, Environmental and Socio-Economic Context of Forests and Tree-Based Systems for Food Security and Nutrition. In: Forests, Trees and Landscapes for Food Security and Nutrition. A Global Assessment Report, p. 51-85. https://www.researchgate.net/publication/276950253. (Last access 26 February 2018).

Pitchers, B., Dufour, L. and Lauri, P.É. (2018). Growing AgroForestry systems with Apple (GAFA project)-Preliminary results on the influence of adult walnut trees on growth and branching of two-year-old apple trees. Acta Horticulturae (this symposium, In Press)

Racsko, J. and Schrader, L.E. (2012). Sunburn of Apple Fruit: Historical Background, Recent Advances and Future Perspectives. Critical Reviews in Plant Sciences 31, 455-504.

Robertson, H., Marshall, D., Slingsby, E. and Newman, G. (2012). Economic, biodiversity, resource protection and social values of orchards: a study of six orchards by the Herefordshire Orchards Community Evaluation Project', Natural England Commissioned Reports, Number 090. http://publications.naturalengland.org.uk/publication/1289011. (Last access 26 February 2018).

Robinson, T.L. (2003), Apple-orchard Planting Systems, In: Apples - Botany, Production and Uses, D.C. Ferree, and I.J. Warrington, eds., CABI Publishing, Wallingford, Cambridge, UK, p. 345-408.

Sapoukhina, N., Durel, C.E. and Le Cam, B. (2009). Spatial deployment of gene-for-gene resistance governs evolution and spread of pathogen populations. Theoretical Ecology 2, 229-238.

Scholes, R.J. and Archer, S.R. (1997). Tree-grass interactions in savannas. Annu. Rev. Ecol. Syst. 28, 517-44.

Simon, S., Lauri, P.É., Brun, L., Defrance, H. and Sauphanor, B. (2006). Does fruit-tree architecture manipulation affect the development of pests and pathogens? - a case study in apple orchard. Journal of Horticultural Science \& Biotechnology 81(4), 765-773.

Simon, S., Bouvier, J.-C., Debras, J.-F. and Sauphanor, B. (2010). Biodiversity and pest management in orchard systems. A review. Agronomy for Sustainable Development 30(1), 139-152.

Simon, S., Brun, L., Guinaudeau, J. and Sauphanor, B. (2011). Pesticide use in current and innovative apple orchard systems. Agronomy for Sustainable Development 31(3), 541- 555.

Simon, S., Lesueur-Jannoyer, M., Plénet, D., Lauri, P.É. and Le Bellec, F. (2017). Methodology to design agroecological orchards: learnings from on-station and on-farm experiences. European Journal of Agronomy 82, 320330.

Smith, J., Crossland, E.M. and Wolfe, M.S. (2016). Silvoarable agroforestry: an alternative approach to apple production? In: Proceedings of the International Farming Systems Association (IFSA), Europe Group, for 2016, 12-15 July 2016, Newport, UK. http://archive.harper-adams.ac.uk/events/ifsa-conference/papers/3/3.3\%20Smith.pdf (Last access 26 February 2018).

Sokalska, D.I., Hamanb, D.Z., Szewczuk, A., Sobota, J. and Deren, D. (2009). Spatial root distribution of mature apple trees under drip irrigation system. Agricultural Water Management 96, 917-924.

Struik, P.C. and Kuyper, T.W. (2017). Sustainable intensification in agriculture: the richer shade of green. A review. Agronomy for Sustainable Development 37: 39. DOI 10.1007/s13593-017-0445-7

Tscharntke, T., Clough, Y., Bhagwat, S.A., Buchori, D., Faust, H., Hertel, D., Hölscher, D. Juhrbandt, J., Kessler, M., Perfecto, I., Scherber, C., Götz S., Veldkamp, E. and Wanger, T.C. (2011). Multifunctional shade-tree management in tropical agroforestry landscapes - a review. Journal of Applied Ecology 48, 619-629.

Tustin, D.S., Dayatilake, G.A., Breen, K.C., and Oliver, M.J. (2012). Fruit set responses to changes in floral bud load a new concept for crop load regulation. Acta Horticulturae 932, 195-202.

Tustin, D.S. and van Hooijdonk, B.M. (2016). Can light interception of intensive apple and pear orchard systems be increased with new approaches to tree design? Acta Horticulturae 1130, 139-144.

UCDAVIS Agricultural Sustainability Institute. (2018). http://asi.ucdavis.edu/programs/sarep/researchinitiatives/are/ecosystem/agroforestry-1 (last access, 1 march 2018) 
van Noordwijk, M., Coe, R. and Sinclair, F. (2016). Central hypotheses for the third agroforestry paradigm within a common definition, Working paper 233, Bogor, Indonesia: World Agroforestry Centre (ICRAF) Southeast Asia Regional Program. DOI: http://dx.doi.org/10.5716/WP16079.PDF (Last access 26 February 2018)..

Weibel, F. and Häseli, A. (2003). Organic Apple Production - with Emphasis on European Experiences. In: Apples Botany, Production and Uses, D.C. Ferree, and I.J. Warrington, eds., CABI Publishing, Wallingford, Cambridge, UK, p. 551-584.

Wezel, A., Casagrande, M., Celette, F., Vian, J.F., Ferrer, A. and Peigné, J. (2014). Agroecological practices for sustainable agriculture. A review. Agron. Sustain. Dev. 34, 1-20.

Willaume, M., Lauri, P.É. and Sinoquet., H. (2004). Light interception in apple trees influenced by canopy architecture manipulation. Trees - Structure and Function 18, 705-713.

Wilson, M.H. and Lovell, S.T. (2016). Agroforestry - The Next Step in Sustainable and Resilient Agriculture. Sustainability 8, 574; doi:10.3390/su8060574.

Wolz, K.J. and DeLucia, E.H. (2018). Alley cropping: Global patterns of species composition and function, Agriculture, Ecosystems and Environment 252, 61-68. 